\title{
Por uma ontologia plural de vozes singulares: 0 embate de Adriana Cavarero com a metafísica
}

\author{
Vozes plurais: filosofia da \\ expressão vocal.
}

CAVARERO, Adriana.

Belo Horizonte: UFMG, $2011.312 \mathrm{p}$.

Em Vozes plurais: filosofia da expressão vocal, Adriana Cavarero subverte a história da metafísica ocidental com uma análise filosófica com ramificações interdisciplinares nas áreas de música, literatura, oralidade e voz, propondo outro modo de pensar a relação entre logos e política, por meio de uma ontologia antimetafísica baseada na pluralidade de vozes singulares. A voz é plural justamente porque é única, incorporada, contextual e relacional.

Docente de Filosofia Política na Universidade de Verona, Cavarero é atualmente uma das pensadoras mais importantes da Itália. Nascida em 1947, a filósofa feminista foi fortemente influenciada pelo pensamento de Hannah Arendt (1906-1975) e é autora de diversos livros, infelizmente não traduzidos para o português até hoje: Nonostante Platone (1990); Corpo in figure. Filosofia e politica della corporeitá (1995); Tu che mi guardi, tu che mi racconti. Filosofia della narrazione (1997); e Orrorismo ovvero della violenza sull'inerme (2007). A pesquisa desenvolvida por Cavarero tem como base a filosofia clássica metafísica e a filosofia política de Hannah Arendt. Desenvolvendo um pensamento complexo e profundo que subverte paradigmas históricos de discursos hegemônicos, Cavarero produz uma obra com um forte cunho feminista.

O pensamento de Cavarero é marcado por diversos temas presentes na filosofia políica de Arendt, aprofundando-os e elaborando-os. Em Vozes plurais, ela parte de questões caras a Arendt em seu texto $A$ condição humana, no qual desenvolve categorias como a pluralidade humana, seres singulares, ação e discurso. Arendt identifica na "pluralidade humana a condição básica da ação e do discurso" (188), afirmando que "a pluralidade humana é a paradoxal plura- lidade de seres singulares" (p. 189). Para a autora, todo ser humano revela a sua identidade única e pessoal através das suas ações e dos seus discursos, e é através da ativação desses discursos e ações que o ser humano se distingue dos outros. Essa distinção singular que é ativada pelos discursos e pelas ações de um sujeito é sempre relacional, em relação aos outros, e é, portanto, política, porque ocorre no coletivo. Todavia, para Arendt, é "o discurso", e não a ação, que efetivamente "corresponde ao fato da distinção" (p. 191). Para ela, é "o discurso" que possibilita a distinção na "condição humana de pluralidade" (p. 191), ou seja, é ele que nos permite sermos distintos e agirmos politicamente entre seres humanos.

Em Vozes plurais, Cavarero, que também incorpora um conhecimento dos estudos de oralidade, não vai se utilizar da categoria "o discurso", mas sim da categoria "a voz". Todavia, a sua definição de voz é complexa, elaborada, e parte em outras direções: a subversão da metafísica, a corporeidade e a política. Esses três aspectos estão ligados entre si na elaboração da sua tese, que é desenvolvida em três partes: Como o logos perdeu a voz, Mulheres que cantam e Por uma política das vozes.

Em Como o logos perdeu a voz, a autora "desconstrói" a metafísica instaurada por Platão e Aristóteles, cujas formulações destituíram o logos de qualquer corporeidade e, portanto, da materialidade da voz, circunscrevendo-o à esfera do pensamento. Para ela, "a história da metafísica deveria ser finalmente contada como a estranha desvocalização do logos" (p. 58). Cavarero nos explica que, na Grécia antiga, a palavra logos derivava do verbo legein, que tinha uma acepção acústica e significava: "falar", assim como "ligar", "contar", "recontar"(p. 43). Platão e Aristóteles desconsideram o aspecto acústico da palavra e mantêm a definição de logos como ligação, ou seja, a linguagem como sistema de significação, no qual, através de um processo mental, a palavra representa o objeto ligando-a a uma imagem. A metafísica aprisiona a voz à esfera semântica, que, por sua vez, é subordinada à esfera visual e, desse modo, transferida à mente (p. 45). A história da meta- 
física tem o seu ponto alto no pensamento cartesiano, no qual o pensar é a condição para o existir, e, nesse seu processo, nega a sua própria matéria, instaurando-se como desvocalização ontológica. Segundo Cavarero, para a filosofia metafísica desvocalizante, "o pensamento não tem voz, não invoca nem fala: cogita" (p. 203).

Duas questões importantes são desdobradas pela autora a partir dessa "desconstrução" do pensamento hegemônico metafísico: política e prazer. Um ponto fundamental se reflete na política individualista de negação do outro, instaurada pela metafísica. Ao sacrificar o aspecto relacional da voz, da emissão e da audição, relegando a palavra à esfera do pensamento, a metafísica não tem que se preocupar com a existência do outro (p. 65). A relação entre logos e política, estabelecida por Platão e Aristóteles, leva ao desenvolvimento de uma política egoísta, centrada no indivíduo, e não no sujeito, porque o sujeito se constitui politicamente numa relação singular com outros sujeitos. Na contramão da metafísica, Cavarero propõe uma política ontológica antimetafísica fundada na singularidade plural da voz que se comunica com outras singularidades vocais.

O segundo desdobramento trazido por Cavarero ao encerrar a primeira parte da sua obra aponta o temor platônico pela carnalidade vocal que invoca o prazer libidinal e o descontrole da razão (p. 107). Ela indica que o canto produzido pelo poeta Homero encanta e produz um prazer acústico com a voz. Fazendo uma ligação entre a épica e o canto associados ao prazer, a autora vai desenvolver a segunda parte da sua obra, que se intitula Mulheres que cantam, através da análise de materiais poéticos, musicais e literários, elaborando relações entre voz, canto, erotismo, materialidade musical da língua e o controle políico por meio da música. O cantar poético, nem sempre por mulheres, é associado ao universo feminino.

Fazendo uma passagem do universo platônico e aristotélico e procurando resgatar a vocalidade subjugada pela metafísica, Cavarero inicia essa segunda parte dando voz às Musas e às Sereias, figuras femininas emblemáticas da antiga Grécia, relacionadas à voz e ao prazer do canto. Musas e Sereias são vistas como perigosas, e, devido aos seus poderes encantatórios, as suas vozes são caladas. Aquelas não têm lugar na república de Platão, visto que o poeta é expulso, e são substituídas pelo filósofo, que tem acesso à verdade (p. 122). Nas representações ocidentais das Musas e das Sereias (p. 131 ), as primeiras continuam "a 'inspirar' versos a poetas que, a rigor, não cantam mais" (p. 131), e as segundas são relegadas à condição de pura voz desprovida de semântica. Ambas perigosas, mas em graus diferentes: as Musas só podem ser ouvidas pelos poetas e, portanto, vinculam algo de perigoso; e as Sereias, com seus poderes encantatórios, podem levar à morte por meio de cantos muitas vezes com tons eróti$\cos ($ p. 131).

Explorando as vozes que cantam, Cavarero aborda as do melodrama; a voz do texto poético a partir de Julia Kristeva, para quem a linguagem está inscrita nas pulsões libidinais do corpo (p. 167); e a "escritura feminina" de Hélène Cixous, que passa por uma língua musical que explode a sintaxe e é relacional porque passa pelo pessoal, um autobiográfico que não segue o estilo tradicional da autobiografia. Embora o cantar não seja restrito às mulheres, ele vem associado a um elemento feminino, que Cavarero exemplifica por meio de uma citação da escritora francesa Cixous, que afirma: "aquilo que canta num 'homem' não é ele, é ela" (149). Para Cavarero, também canta o poeta caribenho Edward Kamau Brathwaite, mas em inglês, num idioma colorido e subvertido pelo creole English e o nation language, que é a língua dos afro-caribenhos. Segundo Brathwaite, a vocalidade se molda influenciada pelos sons do seu ambiente.

Em contraponto à liberdade, corporeidade, subversão e erotismo presentes nas vozes que cantam nessa segunda parte, Cavarero a encerra com uma análise da submissão, feita por Platão, da música à esfera política na qual - logos é desvocalizado. A música não é vista por ele a partir de um universo sonoro, e sim numérico, retirando qualquer analogia ao prazer do som. Àquela é dada a tarefa de disciplinar o logos (p. 190). A metafísica platônica instaura uma política baseada num logos desvocalizado, individualista e centrado na visão.

Em confronto com essa concepção Cavarero desenvolve a terceira e última parte do seu livro, Por uma teoria das vozes. É nela que a autora desenvolve a sua teoria políica de uma ontologia vocálica da unicidade, subvertendo a relação estabelecida entre logos e política pelo pensamento hegemônico da metafísica. Para ela, é preciso revocalizar o logos, permitindo que se instaure uma política relacional singular e não individualista, isto é, plural. A esfera política emerge na comunicacão estabelecida pela pluralidade de vozes singulares corpóreas, que não são discursos abstratos desencarnados, mas que se efetivam nas vozes singulares que se relacionam e que 
são sempre parte de um corpo. A voz, que ancora a palavra no corpo, tornando-a única e pessoal, é central na teoria de Cavarero para subverter o nó criado pela metafísica entre logos e política.

É uma pena que a obra de Adriana Cavarero não tenha tido, até hoje, visibilidade entre os/as pensadores/as feministas e de gênero. A sua obra possui grande rigor na sua empreitada, é de grande escopo, abrangendo a filosofia, a música, a literatura, a oralidade e a voz, e, no Brasil, só foi assimilada por estudiosos de música, teatro e oralidade. Até o momento, não houve qualquer resenha do livro em nenhuma das áreas por ele abarcadas. É prováve que a sua obra não tenha gerado interesse, ainda que desconhecida, entre os/as teóricos/ as feministas e de gênero, porque Cavarero faz parte da assim chamada corrente diferencialista. Todavia, catalogá-la dentro da corrente diferencialista e ignorá-la é um desserviço às discussões correntes feministas e de gênero. A sua investida contra os alicerces do pensamento metafísico ocidental, subvertendo-o ao propor uma ontologia antimetafísica fundada na pluralidade de vozes singulares corpóreas, contextualizadas e relacionais, permite uma teorização da singularidade do sujeito que dialoga com as teorias queers, de gênero e feministas, sejam elas diferencialistas ou igualitárias. Ainda que Cavarero possa associar a materialidade da voz ao feminino, isso é um desdobramento possível na sua formulação teórico-político-relacional mas que não exclui a viabilidade de outros prolongamentos.

Entre as mulheres que cantam, Cavarero identifica vozes singulares de mulheres e de homens, que, na minha perspectiva, não precisam necessariamente estar associados ao aspecto feminino. Essas vozes são singulares e destoam do discurso hegemônico e, justamente por serem sui generis, não cantam em uníssono. A sua teoria abre espaço para muitas outras vozes na pluralidade de gêneros, as quais não têm que se ater ao gênero feminino ou masculino, ainda que possam, de acordo com a singularidade, clamar por um/a, outro/a, ambos, nenhum. E no espaço relacional entre a voz de um sujeito e o ouvido de outro que emerge o político. Quem é o sujeito? É a sua voz - corpórea, semântica, contextual, relacional, singular - que o identifica.

\section{Nota}

'Edward Kamau BRATHWAITE, 1984, citado por CAVARERO 2011, p. 149.

\section{Referências}

ARENDT, Hannah. A condição humana. 10. ed. e 6. reimp. Rio de Janeiro: Forense Universitária, 2007.

Isabella Irlandini

Universidade do Estado de Santa Catarina 